\title{
Profiles of Bacillus spp. Isolated from the Rhizosphere of Suaeda glauca and Their Potential to Promote Plant Growth and Suppress Fungal Phytopathogens
}

Ping Lu' ${ }^{1}$, Ke Jiang ${ }^{1}$, Ya-Qiao Hao ${ }^{1,2}$, Wan-Ying Chu ${ }^{1}$, Yu-Dong Xu${ }^{1}$, Jia-Yao Yang ${ }^{1}$, Jia-Le Chen ${ }^{1}$, Guo-Hong Zeng ${ }^{1}$, Zhou-Hang Gu ${ }^{1 *}$, and Hong-Xin Zhao ${ }^{1 *}$

'Zhejiang Province Key Laboratory of Plant Secondary Metabolism and Regulation, College of Life Sciences and Medicine, Zhejiang Sci-Tech University, Hangzhou 310018, P.R. China

${ }^{2}$ Experimental Teaching Center, College of Life Science, Shenyang Normal University, Shenyang 110034, P.R. China

Members of the genus Bacillus are known to play an important role in promoting plant growth and protecting plants against phytopathogenic microorganisms. In this study, 21 isolates of Bacillus spp. were obtained from the root micro-ecosystem of Suaeda glauca. Analysis of the 16S rRNA genes indicated that the isolates belong to the species Bacillus amyloliquefaciens, Bacillus velezensis, Bacillus subtilis, Bacillus pumilus, Bacillus aryabhattai and Brevibacterium frigoritolerans. One of the interesting findings of this study is that the four strains B1, B5, B16 and B21 are dominant in rhizosphere soil. Based on gyrA, gyrB, and rpoB gene analyses, B1, B5, and B21 were identified as B. amyloliquefaciens and B16 was identified as B. velezensis. Estimation of antifungal activity showed that the isolate B1 had a significant inhibitory effect on Fusarium verticillioides, B5 and B16 on Colletotrichum capsici (syd.) Butl, and B21 on Rhizoctonia cerealis van der Hoeven. The four strains grew well in medium with 1-10\% NaCl, a pH value of 5-8, and promoted the growth of Arabidopsis thaliana. Our results indicate that these strains may be promising agents for the biocontrol and promotion of plant growth and further study of the relevant bacteria will provide a useful reference for the development of microbial resources.

Keywords: Bacillus spp., Suaeda glauca, plant biocontrol, plant growth promotion, Arabidopsis thaliana

Received: May 10, 2021 Accepted: July 12, 2021

First published online: July 15,202

${ }^{*}$ Corresponding authors H.X. Zhao

E-mail: bxxbj2003@sina.com Z.H. Gu

E-mail: hzgu@zstu.edu.cn

Supplementary data for this paper are available on-line only at http://jmb.or.kr.

pISSN 1017-7825 eISSN 1738-8872

CopyrightC 2021 by The Korean Society for Microbiology and Biotechnology

\section{Introduction}

Bacillus species are a group of gram-positive bacteria widely existing in nature [1]. They can produce notable and useful secondary metabolites and are found in diverse environments such as water, soil, vegetation, and even the gastrointestinal tracts of various insects and mammals [2]. This ability to survive and grow in such varied ecosystems is based on the production of endospores that are highly resistant to unfavorable environmental conditions, in addition to their diverse physiological properties and growth requirements [3,4]. When Bacillus species are applied in agriculture, they can bring all kinds of benefits to plants, including strengthening resistance to disease caused by plant phytopathogenic fungi and bacteria, or insects and nematodes [5]. At the same time, they can improve tolerance to stress while promoting plant growth and being eco-friendly $[5,6]$. Many species of Bacillus have been found to secrete gibberellins, plant hormones such as Indole-3-acetic acid (IAA), and some nutrient-solubilizing enzymes that promote the rapid growth of plants [7]. Some physiological changes when plants were inoculated with Bacillus spp. in a stress environment slow down plant senescence [7]. Bacilli also secrete secondary metabolites such as antibiotics, siderophores, and cell wall hydrolases, which contribute to their antagonistic effects against pathogens [5, 8]. In addition, Bacillus spp. can elicit systemic resistance to improve plant resistance against subsequent pathogen attack [8]. It is well known that the roots of plants in the soil are colonized by a plethora of different bacteria and fungi which are largely affected by the physical and chemical properties of the soil and plant genotypes $[9,10]$. However, few reports have investigated the rhizospheric and rhizophilous bacterial microflora in the root micro-ecosystems of halophytes.

Suaeda glauca is a succulent obligate halophyte from the family Chenopodiaceae, and one of the few plant species that can live in highly saline and alkaline soils [11]. It is a significant pioneer species in coastal wetlands of East Asia, and is widely distributed in coastal areas of China [12]. What's more, it is not only an indicator of saline soils but also an ideal plant variety for improving the arability of saline-alkali soils and phytoremediation $[11,13]$. The introduction of halophytes such as S. glauca is beneficial for increasing land utilization rates, enhancing the 
value of saline and solonetzic soils, and economical remediation of mine tailings [12]. In addition to efficiently reducing the salt content of topsoil in which it is cultivated, S. glauca can increase the content of organic matter content as well as nitrogen, phosphorus, and potassium levels in the soil, which generates economic, ecological and social benefits $[14,15]$. These extremely advantageous characteristics make this plant a mighty candidate for saline alkali agriculture and an important source of salt and drought tolerant bacteria, which is why we chose this plant in our research.

In the present study, we set out to explore the diversity of Bacillus species and find novel functional strains. We isolated typical Bacillus spp. from the root micro-ecosystem of S. glauca Bunge, which develops naturally in saline and solonetzic soils with high tolerance of the relatively harsh environmental conditions of Red Beach at Panjin in Liaoning Province $\left(40^{\circ} 41^{\prime}-41^{\circ} 27^{\prime} \mathrm{N}, 121^{\circ} 31^{\prime}-122^{\circ} 28^{\prime} \mathrm{E}\right)$, which is one of the best preserved wetlands in China. The antimicrobial activity and plant growth-promoting effects of selected strains were characterized, and four selected strains were analyzed in more detail. This study provides a reference for exploiting novel microbial resources and as well as for future investigations of the relationship between the dominant plants and associated microorganisms in saline-alkali soils.

\section{Materials and Methods \\ Reagents and Culture Media}

The Qubit 2.0 DNA Kit used for genomic DNA isolation was purchased from NEB (USA). The Taq DNA Polymerase and High-Fidelity DNA Polymerase used for the amplification of $16 \mathrm{~S}$ rRNA genes were purchased from Thermo Fisher Scientific (USA). The DNA gel extraction kit was purchased from GenScript (USA). Unless specifically noted, all other chemicals were obtained from Sigma-Aldrich (USA).

Luria-Bertani (LB) broth containing $10 \mathrm{~g} / \mathrm{l}$ tryptone, $5 \mathrm{~g} / \mathrm{l}$ yeast extract, and $10 \mathrm{~g} / \mathrm{l} \mathrm{NaCl}$ was used for the general cultivation of bacteria or bacterial isolates. Bacillus spp. were grown in LB medium at 30 or $37^{\circ} \mathrm{C}$. Potato dextrose agar (PDA) containing $200 \mathrm{~g}$ peeled potatoes, $20 \mathrm{~g}$ glucose, $15 \mathrm{~g}$ agar, and 1,000 $\mathrm{ml}$ water was used for culturing plant pathogenic fungi. Murashige and Skoog (MS) medium (Sigma-Aldrich) was used as a plant growth medium [16].

\section{Sample Collection and Isolation of Bacillus spp.}

Eight S. glauca Bunge and soil collection sites and ten samples of soil were selected at Red Beach (40 $41^{\prime}-$ $\left.41^{\circ} 27^{\prime} \mathrm{N}, 121^{\circ} 31^{\prime}-122^{\circ} 28^{\prime} \mathrm{E}\right)$. Samples of S. glauca Bunge with rhizosphere soil samples were collected from different soil depths $(0-10 \mathrm{~cm})$ and stored at $4^{\circ} \mathrm{C}$.

Bacillus strains were isolated from ten samples by serial dilution in conjunction with the agar plate method [17]. Soil samples weighing $5 \mathrm{~g}$ were ground and mixed with $9 \mathrm{ml}$ of autoclaved distilled water, shaken thoroughly, and then kept at $70^{\circ} \mathrm{C}$ for $1 \mathrm{~h}$. A $1 \mathrm{ml}$ mixture of this solution was diluted with sterile distilled water at a ratio of 1:10. In addition, each soil sample was serially diluted $10^{-3}$ to $10^{-8}$. Then, $0.1 \mathrm{ml}$ of each dilution was spread on two LB agar plates, one of which was incubated at $30^{\circ} \mathrm{C}$ and the other at $37^{\circ} \mathrm{C}$, for 7 days. Every single colony was picked and sub-cultured on LB agar medium for purification and further studies of colony morphology. Pure bacterial culture suspensions were then grown in LB medium and optical density of cultures at $600 \mathrm{~nm}\left(\mathrm{OD}_{600}\right)$ up to 1.5 , and stored as $20 \%$ glycerol stock at $-80^{\circ} \mathrm{C}$.

\section{S rRNA Sequencing and Phylogenetic Analysis of Bacillus spp.}

Genomic DNA of the bacteria isolated from the root micro-ecosystem of S. glauca Bunge was extracted using the bacterial genomic DNA FastPrep Extraction Kit (Sangon Biotech, China). DNA was quantified on a Nanodrop ND100 spectrophotometer (Thermo Fisher Scientific) and stored at $-20^{\circ} \mathrm{C}$.

The $16 \mathrm{~S}$ rRNA genes from rhizobacterial isolates were amplified using the bacterial universal primers $27 \mathrm{~F}\left(5^{\prime}\right.$ AGTTTGATCMTGGCTCAG-3') and 1492R (5'- GGTTAC CTTGTTACGACTT-3'). PCR was performed in a T1 cycler (Biometra, Germany) in $50-\mu$ reaction systems containing $0.5 \mu \mathrm{M}$ of each primer, $25 \mu \mathrm{l} 2 \times \mathrm{Taq}$ Master Mix (Dye Plus) (Vazyme, China), $1 \mu \mathrm{l}$ of genomic DNA and sterile distilled water (up to $50 \mu \mathrm{l}$ ). Thermal cycling was carried out with a denaturation step at $94^{\circ} \mathrm{C}$ for $3 \mathrm{~min}$, followed by 30 cycles of $45 \mathrm{~s}$ denaturation at $94^{\circ} \mathrm{C}, 45 \mathrm{~s}$ annealing at $56^{\circ} \mathrm{C}$ and $90 \mathrm{~s}$ elongation at $72^{\circ} \mathrm{C}$, with a final elongation step at $72^{\circ} \mathrm{C}$ for $5 \mathrm{~min}$, then cooled to $4^{\circ} \mathrm{C}$. The PCR products were further sequenced and verified by Sangon Biotech (China) after purifying with a QIAquick-PCR purification column (Qiagen, Germany). A sequence similarity search was conducted using GenBank BLAST. The phylogenetic tree was constructed using MEGA7 software with bootstrap analysis using 1,000 replications to assess the relative stability of the branches. All 16S rRNA gene sequences from the isolates were submitted to the NCBI GenBank Database under an accession number.

\section{Cloning and Partial Sequence Analysis of the gyrA, gyrB and $r p o B$ Housekeeping Genes}

The partial sequences of the three housekeeping genes $g y r A, \operatorname{gyr} B$, and $r p o B$ were amplified using the specific primers gyrA F (5'-CAGTCAGGAAATGCGTACGTCC TT-3'): gyrA R (5'-CAAGGTAATGCTCCAGGCATTGCT-3'), gyrB F (5'-TTATCTACGACCTTAGA CG-3'): gyrB R (5'-TAAATTGAAGTCTTCTCCG-3') [18], and rpoB F (AGGTCAACTAGT TCAGTATGGAC): $r p o B$ R (5'-AAGAACCA TAACCGGCAACTT-3'), respectively [19]. The $50 \mu \mathrm{l}$ PCR reaction system contained $5 \mu \mathrm{l}$ of the $10 \times$ PCR buffer, $2 \mu \mathrm{l}$ dNTPs, $1 \mu \mathrm{l}$ Pfu DNA polymerase (Takara Bio Inc., China), $3 \mu$ lgenomic DNA template ( $25 \mathrm{ng} / \mu \mathrm{l} \mathrm{DNA}), 2 \mu \mathrm{l}$ of each of the primers $(0.1 \mu \mathrm{M})$ and $35 \mu \mathrm{l}$ of the deionized distilled water (DDW). The temperature program included a denaturation step at $94^{\circ} \mathrm{C}$ for $5 \mathrm{~min}$, followed by 30 cycles of $95^{\circ} \mathrm{C}$ for $1 \mathrm{~min}$, annealing at $50 \sim 63^{\circ} \mathrm{C}$ for $30 \mathrm{~s}$, and elongation at $72^{\circ} \mathrm{C}$ for $1 \mathrm{~min}$, followed by a final elongation cycle at $72^{\circ} \mathrm{C}$ for $5 \mathrm{~min}$, after which the PCR product was kept at $4^{\circ} \mathrm{C}$. For Sanger sequencing, 
$20 \mu$ of the PCR product purified using the DNA gel extraction kit (Qiagen) was sent to Sangon Biotech (China). Results of sequencing were analyzed using Chromas V 1.45, DNAMAN 8.0, MEGA7 and Blast software at the NCBI site. The partial sequences of the tree housekeeping genes from the isolates were submitted to the NCBI GenBank Database under an accession number (Fig. 3).

\section{Screening for Antifungal Bacteria and Testing of Antifungal Activity}

Twelve plant-pathogenic fungi (including Fusarium oxysporum, Fusarium graminearum Sehw, Rhizoctonia cerealis van der Hoeven, Gaeumannomyces graminis (sacc.), Botrytis cinereal Pers., Botryosphaeria dothidea, Colletotrichum gloeosporioides Penz, Fusarium oxysporum f. sp. niveum, Colletotrichum capsici (syd.) Butl., Fusarium verticillioides, F. oxysporum $\mathrm{f}$. $\mathrm{sp}$. vasinfectum (Atk) and $F$. oxysporum $\mathrm{f}$. sp. lilii (for more details see Table S1), all of which were originated from plants including agricultural crops, fruits and vegetables, were provided by the Institute of Plant and Environment Protection (IPEP) of Beijing Academy of Agriculture and Forestry Sciences (BAAFS) and exposed to the isolated bacteria to assess their antifungal spectrum. To measure the antifungal activity of the bacteria, a mycelial disk ( $5 \mathrm{~mm}$ in diameter) of each plant-pathogenic fungus from a 5-day-old culture was placed at the edge of a PDA medium plate, $25 \mathrm{~mm}$ away from each streaked bacterial inoculum $\left(10^{6} \mathrm{CFU} / \mathrm{ml}\right)$, which was placed in the middle of the plate. Then, the plate was incubated at $25^{\circ} \mathrm{C}$ for 5 8 days. Inhibition of mycelial growth of each fungus was then measured, and the inhibitory effect of the antagonistic bacteria was assessed by the radial growth inhibition percentage.

\section{Tolerance of Isolates to Salinity and Alkalinity}

The antagonistic bacteria screened in the antifungal activity test were then further characterized for their ability to tolerate salinity and alkalinity. The $\mathrm{NaCl}$ concentration in the $\mathrm{LB}$ broth was varied from $0.1 \%$ to $15 \%$, and the $\mathrm{pH}$ value was adjusted from 3 to 10 with $1 \mathrm{~mol} / \mathrm{l}$ sodium hydroxide $(\mathrm{NaOH})$ or $1 \mathrm{~mol} / \mathrm{l}$ hydrochloric acid $(\mathrm{HCl})$ for the alkalinity test. The seed cultures of the antagonistic strains were used to inoculate 250 -ml flasks containing $30 \mathrm{ml}$ of LB medium and grown at $30^{\circ} \mathrm{C}$ and $150 \times g$ for $20 \mathrm{~h}$. Cell proliferation was monitored by measuring the $\mathrm{OD}_{600}$.

\section{Ability of the Isolates to Promote the Growth of Arabidopsis thaliana}

Seeds of $A$. thaliana ecotype Columbia (Col-0) were surface-sterilized by soaking in $75 \%$ ethanol for $2 \mathrm{~min}$, followed by soaking in $1 \%$ sodium hypochlorite $(\mathrm{NaOCl})$ for $20 \mathrm{~min}$. The seeds were thoroughly washed three times with sterile distilled water and then germinated in Petri dishes with half-strength Murashige and Skoog (MS) medium containing $0.8 \%$ agar and $1.5 \%$ sucrose, and the $\mathrm{pH}$ was adjusted to 5.7 [16]. The seeds were then vernalized for 2 days at $4^{\circ} \mathrm{C}$ in darkness. The resulting seedlings were placed in growth cabinets and subjected to a 12 -h light/dark cycle under $40 \mathrm{~W}$ fluorescent lights at a constant temperature of $22^{\circ} \mathrm{C}$ and relative humidity of 50 $60 \%$. Germinated seedlings were transferred to plates after 2 days to test the ability of the bacterial strains to promote the growth of $A$. thaliana [16].

The bacterial strains were cultured overnight at $30^{\circ} \mathrm{C}$ in LB medium, and then diluted with sterile distilled water to yield $10^{9} \mathrm{CFU} / \mathrm{ml}$ based on the $\mathrm{OD}_{600}$ and the number of colonies counted on plates for the various serial dilutions. Plastic Petri dishes $(100 \times 15 \mathrm{~mm})$ with a central partition were filled with Murashige and Skoog solid medium, and 2-day-old germinated $A$. thaliana seedlings ( 9 seedlings per plate) were transferred to one side of each plate. The plants were inoculated with $10 \mu \mathrm{l}$ bacterial strain solution $\left(10^{9} \mathrm{CFU} / \mathrm{ml}\right.$ ) or sterile distilled water (as control) at the center of the other side of the plate that did not contain the seedling. After 2 weeks of incubation, the total number of leaves and the leaf and fresh stem weights were measured to evaluate the growth-promoting effect of the bacteria [16]. The assay was repeated three times each with nine biological replicates $(n=3 \times 9=27)$ for each treatment.

\section{Statistical Analysis}

The significance of differences was assessed using analysis of variance (ANOVA) in SPSS20.0 software (IBM Corp., USA). The antibacterial effect of four Bacillus sp. strains on 12 fungal pathogens was determined by the following formula: $\mathrm{IR}=(\mathrm{R} 1-\mathrm{R} 2) / \mathrm{R} 1 \times 100 \%$, where $\mathrm{R} 1$ is the radial growth of the plant-pathogenic fungus on the control plate, and R2 is the radial growth of the plant pathogenic fungus interacting with the antagonistic strain. The effect of the treatment with growth promotion of $A$. thaliana was determined based on the magnitude of the $F$ value $(p=0.05)$. When the ANOVA was significant $(p \leq 0.05)$, means were separated with Duncan's test.

\section{Results}

Isolation and Screening of Bacillus spp. from the Root Micro-Ecosystem of S. glauca Bunge

Eight soil collection sites encompassing diverse habitats such as offshore, riverway, tributary, swale, etc., were selected at Red Beach, and ten soil samples from the rhizosphere of S. glauca Bunge (labeled as Sg-01 through Sg10) were collected and refrigerated at $4^{\circ} \mathrm{C}$. A total of 103 strains were isolated as described in Materials and Methods. The isolates were further identified based on their morphological characteristics such as size, color, colony edge shape, and viscosity, and also according to the results of Gram staining and microscopic observation. Based on obviously different morphological characteristics, 21 isolates were suspected to be different strains (see Table S2 in the supplemental material) and chosen for further identification by $16 \mathrm{~S}$ rRNA gene sequencing.

The analysis of $16 \mathrm{~S}$ rRNA sequences indicated that the 21 isolates, which were collected from the root microecosystem of S. glauca Bunge, could be categorized into five clusters (Fig. 1). However, the isolates belonged to only 


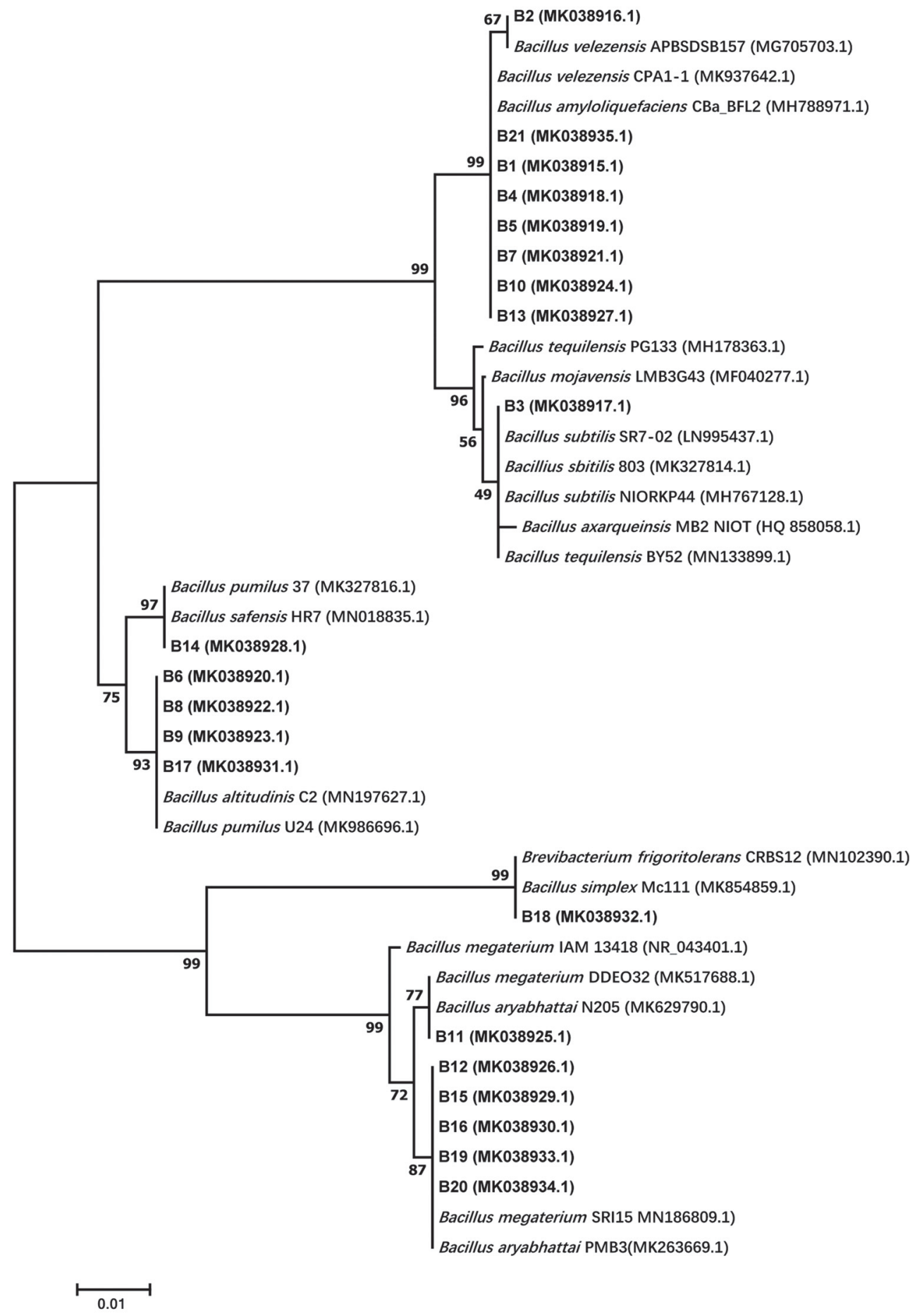

Fig. 1. Phylogenetic tree based on the $16 \mathrm{~S}$ rDNA sequences of Bacillus spp. strains isolated from the rhizosphere of S. glauca constructed using the neighbor-joining method.

two genera, Brevibacterium and Bacillus. Among the isolates, only a single strain of Brevibacterium was obtained, and was identified as Brevibacterium frigoritolerans, while among the Bacillus species, eight strains were identified as Bacillus velezensis, one was Bacillus subtilis, five were Bacillus pumilus, and six were determined as Bacillus aryabhattai.

Screening and Analysis of the Antifungal Activity of the Isolated Bacillus Strains

The 21 isolated bacterial strains were tested for their ability to inhibit or prevent mycelial growth of fungal plant pathogens, and four Bacillus sp. strains labeled as B1, B5, B16 and B21 showed apparent antifungal activity, 


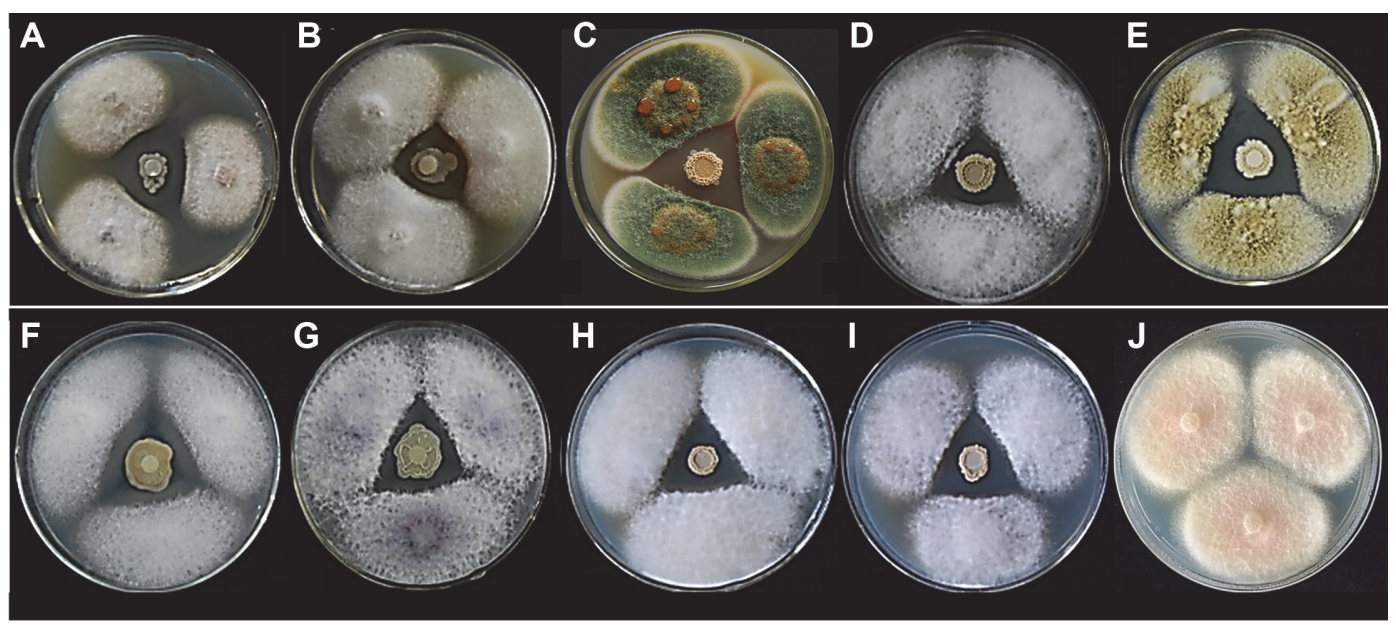

Fig. 2. Antifungal effects of the isolated Bacillus spp. strains against different plant-pathogenic fungi (A: B1 against F. oxysporum; B: B1 against B. cinerea Pers.; C: B1 against $G$. graminis (sacc.); D: B5 against $R$. cerealis van; E: B5 against C. capsici (syd.) Butl.; F: B16 against F. oxysporum f. sp. lili; G: B16 against F. oxysporum; H: B21 against B. dothidea; I: B21 against B. cinereal Pers; J: F. graminearum Sehw against F. graminearum Sehw as one of the controls).

Table 1. Inhibition rates of the four Bacillus sp. strains against 12 fungal pathogens.

\begin{tabular}{lcccc}
\hline \multicolumn{1}{c}{ The tested strains } & \multicolumn{3}{c}{ Inhibition rate $(\%)$} \\
\cline { 2 - 5 } & B1 & B5 & B16 & B21 \\
\hline F. oxysporum & 39.52 & 25.54 & 24.73 & 13.71 \\
F. graminearum Sehw & 61.51 & 59.83 & 62.54 & 39.23 \\
R. cerealis van & 47.44 & 60.35 & 48.68 & 73.52 \\
G. graminis (sacc.) & 26.35 & 37.04 & 23.08 & 8.55 \\
B. cinereal Pers. & 56.13 & 43.14 & 52.51 & 43.79 \\
B. dothidea & 58.86 & 61.40 & 70.22 & 71.66 \\
C. gloeosporioides Penz & 37.61 & 25.86 & 20.98 & 10.34 \\
F. oxysporum f. Sp. niveum & 45.75 & 66.17 & 67.41 & 68.15 \\
C. capsici (syd.) Butl. & 60.46 & 72.95 & 74.56 & 69.74 \\
F. verticillioides & 27.02 & 24.48 & 15.95 & 5.31 \\
F. oxysporum f. sp. lilii & 67.41 & 65.08 & 67.20 & 66.67 \\
F. oxysporum f. sp. vesinfectum (Atk) & 67.69 & 42.31 & 51.28 & 48.08 \\
\hline
\end{tabular}

especially against C. capsici (syd.) Butl., F. verticillioides, R. cerealis van, G. graminis (sacc.), B. cinerea Pers. and B. dothidea (Fig. 2 and Table 1).

Table 1 lists the results of the antagonistic activity test for each isolate. The inhibition rates of the four Bacillus sp. strains were monitored by measuring the width of the inhibition zone (see Table S3 in the supplemental material). Strain B1 was more effective against F. oxysporum f. sp. vesinfectum (Atk.) and F. oxysporum, with 67.69\% and $67.41 \%$ antimicrobial rate, respectively. Strain B5 was the most effective strain against C. capsica (syd.) Butl., with $72.95 \%$ antimicrobial rate, followed by $66.17 \%$ and $65.08 \%$ antimicrobial rate against $F$. verticillioides and $F$. oxysporum f. sp. lilii. Strain B16 was the most effective bacterium against $C$. capsica (syd.) Butl. (74.56\%), followed by $70.22 \%$ and $67.41 \%$ antimicrobial rate against B. dothidea and F. oxysporum f. sp. niveum, whereas strain B21 was the most effective against $R$. cerealis van up to $73.52 \%$, and close to B. dothidea up to $71.66 \%$. These results demonstrated that all four Bacillus strains exhibited broad-spectrum antifungal activity.

Analysis of $g y r A, g y r B$, and rpoB Housekeeping Genes, and 16S rRNA Gene from B1, B5, B16, and B21

Based on the inhibition of the mycelial growth of fungal plant pathogens, B1, B5, B16, and B21 appeared to have distinct antifungal activity. However, the 16S rRNA analysis showed that B1, B5, and B21 were strains of B. velezensis, with sequence identities from 99 to $100 \%$. The $16 \mathrm{~S}$ rRNA gene sequence sometimes has a limited ability to reliably distinguish taxa at the species level due to the conserved nature of the gene [19]. In order to further phylogenetically analyze B1, B5, B16, and B21, the housekeeping genes $\operatorname{gyr} A$, gyrB, and $r p o B$, which respectively code for major subunits of the DNA Gyrase and RNA polymerase, were also employed for identification $[18,19]$. Phylogenetic trees were constructed using the $16 \mathrm{~S}$ rRNA gene sequences (Fig. 3A), the $r p o B$ gene sequence for B1, B5, B16, and B21 (Fig. 3B), the gyrA gene sequence (Fig. 3C), and the gyrB gene sequence (Fig. 3D). The analysis of the $16 \mathrm{~S}$ rRNA genes of B1, B5, B16, and B21 analysis showed that B1, B5, and B21 clustered with B. velezensis, B. amyloliquefaciens or B. siamensis while B16 clustered with B. aryabhattai or $B$. megaterium (Fig. 3A). The sequence analysis of the housekeeping gene $r p o B$, which encodes one of the subunits 

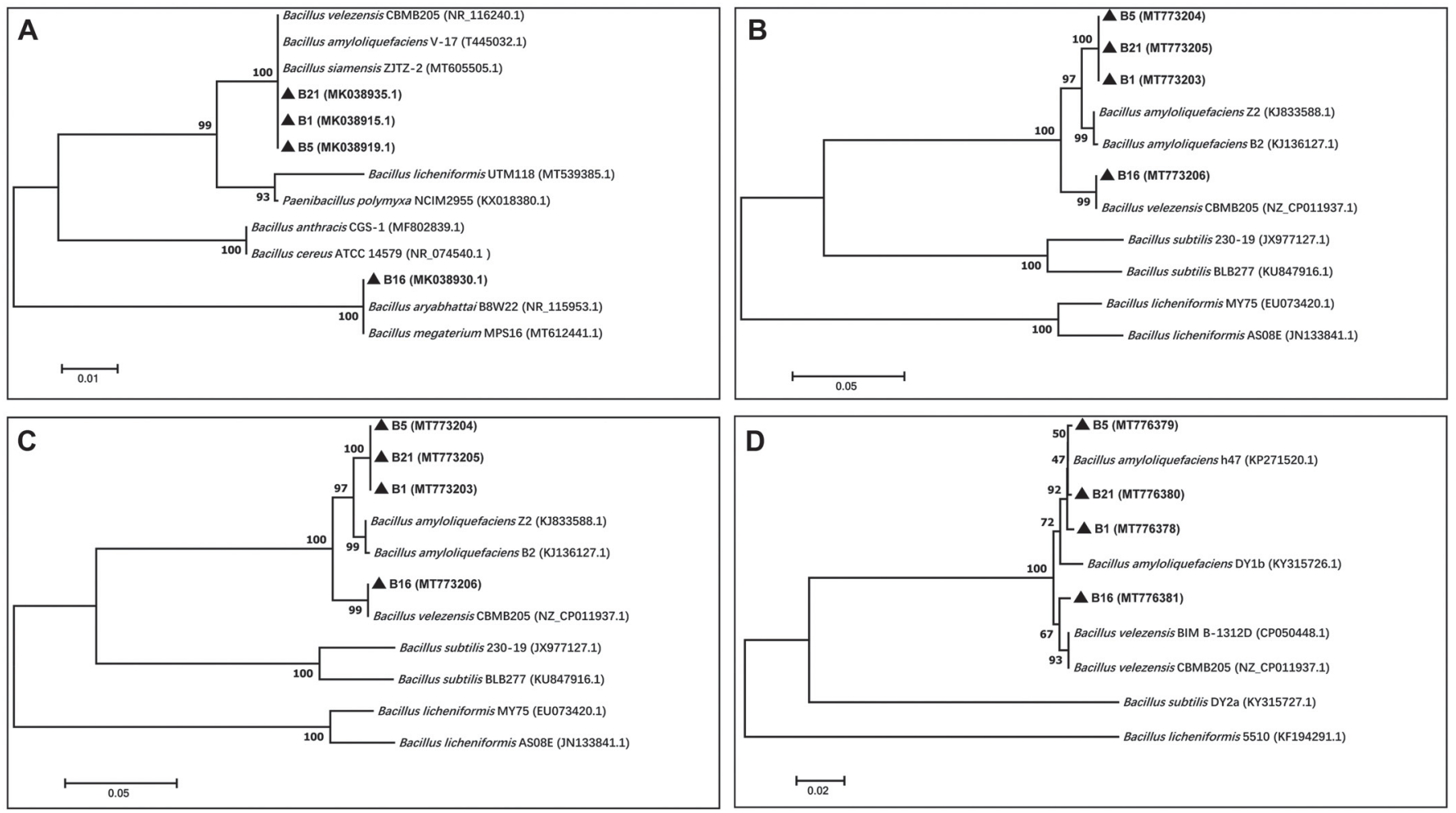

Fig. 3. Phylogenetic tree of the antifungal Bacillus strains B1, B5, B16, and B21 generated using the neighbor-joining method based on the $16 \mathrm{~S}$ rDNA gene sequences $(\mathrm{A})$, and the $\operatorname{rpoB}(\mathrm{B}), \operatorname{gyrA}(\mathrm{C})$, and $g y r B$ gene sequences $(\mathrm{D})$.

of RNA polymerase, differentiated the isolates $\mathrm{B} 1, \mathrm{~B} 5, \mathrm{~B} 21$, and $\mathrm{B} 16$. The analysis of $r p o \mathrm{~B}$ revealed that $\mathrm{B} 1, \mathrm{~B} 5$, and B21 showed high similarity (Fig. 3B), while B16 was more distant. Based on gyrA gene sequence analysis, B1, B5, B21 were identified as B. velezensis, and B16 was identified as B. amyloliquefaciens (Fig. 3C). Based on gyrB gene sequence analysis, B1, B5, B21 were identified as B. amyloliquefaciens and B16 was identified as B. velezensis (Fig. 3D). The nucleotide and amino acid changes in $g y r A, g y r B$, and $r p o B$ of B1, B5, B16, and B21 compared with the reference strain B. velezensis strain CBMB205 (NZ_CP011937.1), and the frequency of nucleotide and amino acid substitutions among the different groups are listed in Table 2. The gyrA sequence of B16 was identical to that of B. velezensis, while $\mathrm{G}(457)$ and $\mathrm{T}$ (573) of gyrA in the other strains were changed into $\mathrm{T}$ and $\mathrm{C}$, respectively, whereas Ala (153) and Val (158) were changed into Ser and Ala accordingly. T (324) of $r p o B$ in the four strains was changed into $C$ and $G$ (276) of B1, B5, and B21 were changed into $A$, but all of their amino acid sequences showed no differences. A (548) of gyrB in B1, B5, and B21 was changed into T, C (494) in B1, T (533) in B5, G (460) in B21, and $\mathrm{G}$ (884) in B16 were changed into T, G, A, and A, respectively. Accordingly, Glu (183) in B1, B5, and B21 was changed into Val, while Thr (163) in B1, Phe (178) in B5, Ala (154) in B21 and Arg (195) in B16 were respectively changed into Ile, Cys, Thr, and His. The comparison results of the three housekeeping genes gyrA, gyrB, and $r p o B$ showed that B1, B5, and B21 could belong to different strains of the same species called B. amyloliquefaciens.

Table 2. Classification of BI, B5, B16, and B21 based on distribution of $g y r A, g y r B$, and $r p o B$ genes nucleotide and amino acid changes.

\begin{tabular}{|c|c|c|c|c|c|c|c|c|}
\hline \multirow{2}{*}{$\begin{array}{c}\text { Gene } \\
\text { (5'partial) }\end{array}$} & \multicolumn{4}{|c|}{ Nucleotide change } & \multicolumn{4}{|c|}{ Amino acid change } \\
\hline & B1 & B5 & B21 & B16 & B1 & B5 & B21 & B16 \\
\hline $16 S r D N A$ & - & - & - & - & - & - & - & - \\
\hline \multirow[t]{2}{*}{ gyrA } & $\mathrm{G}(457) \rightarrow \mathrm{T}$ & $\mathrm{G}(457) \rightarrow \mathrm{T}$ & $\mathrm{G}(457) \rightarrow \mathrm{T}$ & - & $\mathrm{Ala}(153) \rightarrow$ Ser & $\mathrm{Ala}(153) \rightarrow$ Ser & $\mathrm{Ala}(153) \rightarrow$ Ser & - \\
\hline & $\mathrm{T}(573) \rightarrow \mathrm{C}$ & $\mathrm{T}(573) \rightarrow \mathrm{C}$ & $\mathrm{T}(573) \rightarrow \mathrm{C}$ & - & $\operatorname{Val}(158) \rightarrow$ Ala & $\operatorname{Val}(158) \rightarrow$ Ala & $\mathrm{Val}(158) \rightarrow$ Ala & - \\
\hline \multirow[t]{2}{*}{ gyrB } & $\mathrm{C}(494) \rightarrow \mathrm{T}$ & $\mathrm{T}(533) \rightarrow \mathrm{G}$ & $\mathrm{G}(460) \rightarrow \mathrm{A}$ & $\mathrm{G}(884) \rightarrow \mathrm{A}$ & $\operatorname{Thr}(163) \rightarrow$ Ile & Phe $(178) \rightarrow$ Cys & $\mathrm{Ala}(154) \rightarrow \mathrm{Th} \mathrm{r}$ & $\operatorname{Arg}(195) \rightarrow \mathrm{His}$ \\
\hline & $\mathrm{A}(548) \rightarrow \mathrm{T}$ & $\mathrm{A}(548) \rightarrow \mathrm{T}$ & $\mathrm{A}(548) \rightarrow \mathrm{T}$ & - & Glu $(183) \rightarrow \mathrm{Val}$ & $\mathrm{Glu}(183) \rightarrow \mathrm{Val}$ & Glu $(183) \rightarrow \mathrm{Val}$ & - \\
\hline \multirow[t]{2}{*}{$r p o B$} & $\mathrm{G}(276) \rightarrow \mathrm{A}$ & $\mathrm{G}(276) \rightarrow \mathrm{A}$ & $\mathrm{G}(276) \rightarrow \mathrm{A}$ & $\mathrm{T}(324) \rightarrow \mathrm{C}$ & - & - & - & - \\
\hline & $\mathrm{T}(324) \rightarrow \mathrm{C}$ & $\mathrm{T}(324) \rightarrow \mathrm{C}$ & $\mathrm{T}(324) \rightarrow \mathrm{C}$ & - & - & - & - & - \\
\hline
\end{tabular}

The gyrA, gyrB, and rpoB from B. velezensis CBMB205 (NZ_CP011937.1) as reference, when phylogenetically analyzing B1, B5, $\mathrm{B} 16$, and $\mathrm{B} 21$ by three housekeeping genes cloned from B1, B5, B16, and B21. The $16 \mathrm{~S}$ rDNA gene from $B$. velezensis CBMB205 and B. aryabhattai B8W22 as reference, when phylogenetically analyzing B1, B5 and B21, and B16 by 16 rDNA genes cloned from B1, B5, B21, and B16, respectively. "-" means no change. 
A

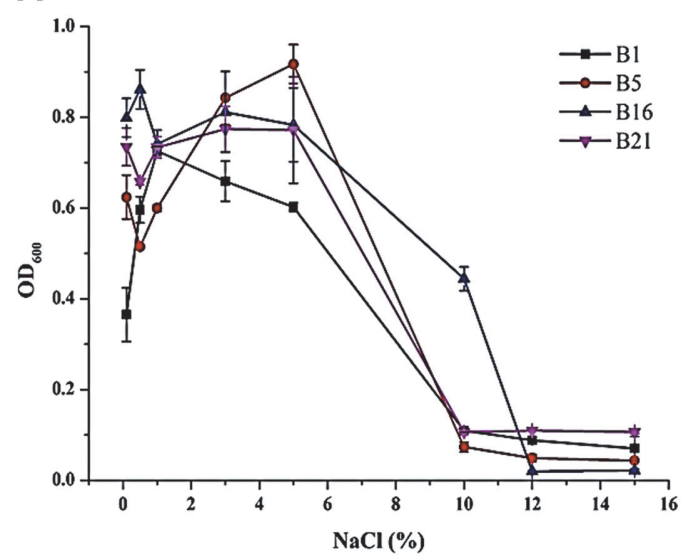

B

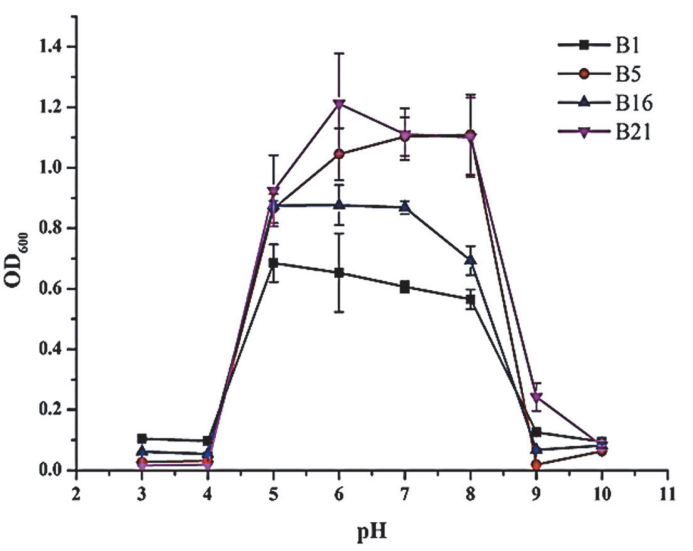

Fig. 4. Resistance to salinity and alkalinity of the four antifungal Bacillus strains.

Salinity and Alkalinity Resistance of the Antifungal Bacillus Strains

The effects of salinity and alkalinity on the proliferation of the strains B1, B5, B16, and B21, which exhibited broad-spectrum antifungal activities, were also assessed (Fig. 4). Salt tolerance differed substantially among the strains. The salt concentration that could be tolerated by the strains ranged from $0.1 \%$ to $10 \%$ (Fig. $4 \mathrm{~A}$ ). All strains grew well at $1 \%$ salt concentration ( $10 \mathrm{~g} / \mathrm{l} \mathrm{NaCl}$; i.e., normal $\mathrm{LB}$ medium $)$, with a growth potential of up to $10 \%$. The $\mathrm{OD}_{600}$ of $\mathrm{B} 5$ reached its maximum of 0.9 when the concentration of $\mathrm{NaCl}$ was $5 \%$. However, only $\mathrm{B} 16$ could grow in medium with $10 \% \mathrm{NaCl}$. The relative salt tolerance of the strains within the $\mathrm{NaCl}$ range $1-10 \%$ was in the order $\mathrm{B} 5$ $>$ B16 > B21 > B1. All strains stopped growing when exposed to salt concentrations above $12 \%$.

An acid-alkali tolerance test was carried out in LB media with different $\mathrm{pH}$ values ( 3 to 10). The four Bacillus strains all grew normally in the $\mathrm{pH}$ range of 5-8 (Fig. 4B), but their optimal $\mathrm{pH}$ values were quite different as the strains $\mathrm{B} 1$ and $\mathrm{B} 16$ grew best at $\mathrm{pH} 5-7$, while $\mathrm{B} 5$ and $\mathrm{B} 21$ showed the best growth at $\mathrm{pH}$ 6-8. None of the strains grew well at $\mathrm{pH} \leq 4$ or $>8$.

\section{Ability of the Four Bacillus sp. Strains to Promote the Growth of A. thaliana}

To assess the growth-promoting effect of the four antimicrobial strains, A. thaliana was cultivated with B1, B2, B16, B21 and sterile water (as control) in solid medium on the same plate (Fig. 5) ( $n=27)$. Compared with the control group, each strain could promote the growth of $A$. thaliana, albeit to different extents. The growthpromoting effect was assessed based on the increase of the number of leaves and the fresh weight of the combined stems and leaves (Table 3). Strains B1, B5, and B21 significantly promoted the growth of leaves, while strains B1, $\mathrm{B} 16$, and B21 were relatively more effective in promoting the increase of leaf-stem fresh weight.

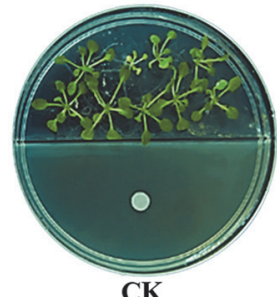

CK

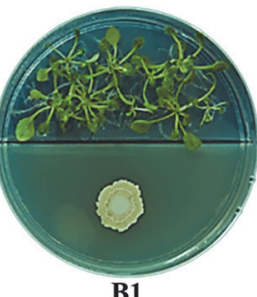

B1

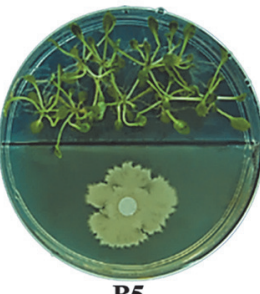

B5

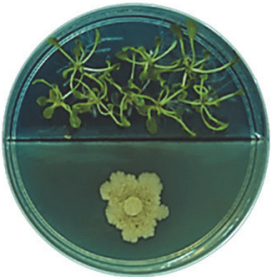

B16

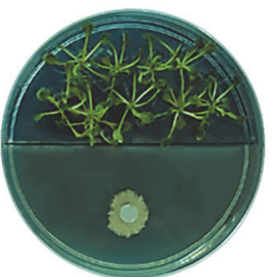

B21

Fig. 5. Plant growth promotion analysis of the four Bacillus sp. strains on $A$. thaliana compared with water treatment (control).

Table 3. Abilities of four Bacillus sp. strains to promote growth of $A$. thaliana $(n=27)$.

\begin{tabular}{ccc}
\hline Treatment & Number of leaves & Leaf and stem fresh weight $(\mathrm{mg})$ \\
\hline CK & $8.88 \pm 0.99^{\mathrm{c}}$ & $25.39 \pm 8.28^{\mathrm{c}}$ \\
B1 & $10.38 \pm 0.74^{\mathrm{ab}}$ & $30.79 \pm 6.50^{\mathrm{bc}}$ \\
B5 & $11.25 \pm 1.04^{\mathrm{a}}$ & $38.38 \pm 8.62^{\mathrm{ab}}$ \\
B16 & $9.75 \pm 0.71^{\mathrm{bc}}$ & $40.89 \pm 3.72^{\mathrm{a}}$ \\
B21 & $11.00 \pm 1.07^{\mathrm{a}}$ & $34.51 \pm 7.99^{\mathrm{ab}}$ \\
\hline
\end{tabular}

$\mathrm{a}, \mathrm{b}$, and $\mathrm{c}$ results refer to average of triplicates \pm SD. The mean difference is significant $(p<0.05)$. Same letter in column was used as a notation for statistical analysis; $\mathrm{CK}$ (control): $A$. thaliana were cultivated at sterile water. 


\section{Discussion}

Plant roots growing in special environments such as wetlands or highly alkaline soil can produce a broad variety of metabolites to adapt to the environment and attract or select special microorganisms in the rhizosphere [20]. A variety of microorganisms form a complex micro-ecosystem and establish a dynamic balance with plants [21]. However, there are few studies on the diversity and distribution of micro-ecosystem and endophytic bacteria associated with plants and their potential functions [21, 22]. Previously, we analyzed the microbial colony structure of the S. glauca Bunge root micro-ecosystem by high-throughput sequencing [23]. The analysis yielded a total of 143,041 effective sequences, 1,346 OTUs, 27 phyla, 60 classes, 104 orders, 193 families, 355 genera, and 408 species [23]. The abundance of microbial species inhabiting the roots of $S$. glauca may provide clues for understanding the salt and alkali tolerance traits of S. glauca [24]. Thus, the results in this investigation may provide further detailed information for the composition and diversity of the rhizosphere bacterial microbiome of the halophyte S. glauca Bunge. In order to expand our understanding of the diversity of culturable salt-tolerant rhizospheric bacteria from the roots of halophyte S. glauca Bunge, we isolated and identified different species of rhizospheric bacteria from 10 sampling sites. However, it is worth mentioning that 103 strains were isolated from the root micro-ecosystem of S. glauca Bunge. According to the obviously different morphological characteristics, 21 isolates were suspected to be different strains. Based on the analysis of $16 \mathrm{~S}$ rRNA sequences, the isolates belonged to only two genera, Brevibacterium and Bacillus. B. velezensis, B. subtilis, B. pumilus, B. aryabhattai and B. frigoritolerans were found among the identified isolates. It was shown that the Bacillus spp. is the dominant phyla in S. glauca. Similar phyla were presented by Yamamoto et al. [25] who studied the diversity of endophytic and rhizospheric bacteria of the halophytes S. europaea and Glaux maritima. What's more, Bouizgarne [26] reported that Bacillus spp. could mainly colonize in the rhizosphere of plants. Generally, Bacillus spp. may play significant roles in the life of S. glauca and other halophytes [27-29], as bacteria could produce certain antifungal and antibacterial metabolites [30-32] including the notable proteins iturin and chitinase [5].

Rhizosphere bacteria are well known inhabitants of living plant systems and play an important role in maintaining plant growth and health. In this examination, four Bacillus sp. strains labeled as B1, B5, B16, and B21 showed apparent antifungal activity, which may indicate their high antifungal ability under saline conditions. In another investigation, fresh fruits such as strawberry and golden delicious were infected with $B$. cinerea Pers., and fought against with Bacillus sp. (B16) at room temperature for more than 12 days. The results showed that Bacillus sp. (B16) also has good resistance to plant pathogenic bacteria on real fruits (data not shown). Based on the data obtained from the literature, Bacillus species obtained from soil or aerial parts of plants have been proven to be superb producers of antibacterial compounds and have the potential to control fungi and phytopathogenic bacteria [33, 34]. Kupper et al. [35] found that most Bacillus isolates produce volatile metabolic compounds that inhibit the development of pathogens and the production of two antibiotics (iturin and surfactant) can be detected in B. subtilis ACB-83. Similar results were found by Asari et al. [36] who used B. amyloliquefaciens strains to control pathogens and showed that the isolates can effectively produce volatile organic compounds with antibacterial effects in vitro. And Leelasuphakul et al. [37] found that volatile organic compounds (alcohols) produced by Bacillus can inhibit the growth of fungi. Furthermore, based on the genome sequence analysis of $B$. velezensis $\mathrm{C} 4341$ isolated from saline soil samples, Zhu et al. [38] presented that genes related to biofilm formation, iron acquisition, colonization, and synthesis of volatile organic compounds were found in the genome of $B$. velezensis. These genes play an important role in the process of biological control. Notably, it seems that four Bacillus sp. strains not only have high antifungal ability but also other abilities such as promoting the growth of plants. To assess the growth-promoting effect of the four antimicrobial strains, $A$. thaliana was cultivated with B1, B5, B16, B21 and sterile water (as control) in solid medium on the same plate. All of the A. thaliana showed a significant enhancement in plant growth compared with control seedlings (Fig. 5). Recently, several Bacillus spp. including B1, B5, B16, and B21, were also investigated for their ability to promote the growth of Nicotiana benthamiana (data not shown). The results indicated that the growth characteristics of $N$. benthamiana were similar to those of $A$. thaliana Columbia (Col-0). These findings were also to a report by Kushwaha, who found various species of endophytic Bacillus in pearl millet with excellent growth promotion and biocontrol activities [39]. Therefore, it has been indicated that B1, B5, B16, and B21 have potential applications in agriculture and biotechnology. Moreover, many Bacillus isolates can fix nitrogen and also be used for biocontrol of the sugarcane pathogens Ceratocystis paradoxa and Sporisorium scitamineum [40]. Nitrogen-fixing species can be used as a fertilizer, in addition to their biocontrol effects [40,41]. Hence, diverse species of the genus Bacillus are valuable bioresources for agro-biotechnological applications due to their plant growth-promoting and biological control effects [6], which was consistent with our findings.

Salinity and alkalinity can greatly reduce the growth and productivity of sensitive plants. The effects of salinity and alkalinity on the proliferation of the strains B1, B5, B16, and B21, were also assessed in this examination. However, these strains showed considerable variation in salt and alkaline tolerance. The relative salt tolerance of the strains within the $\mathrm{NaCl}$ range 1-10\% was in the order $\mathrm{B} 5>\mathrm{B} 16>\mathrm{B} 21>\mathrm{B} 1$. Besides, the four Bacillus strains all grew normally in the $\mathrm{pH}$ range of 5-8, but their optimal $\mathrm{pH}$ values were quite different as the strains $\mathrm{B} 1$ and $\mathrm{B} 16$ grew best at $\mathrm{pH}$ 5-7 while $\mathrm{B} 5$ and $\mathrm{B} 21$ showed the best growth at $\mathrm{pH}$ 6-8. This may indicate the high diversity of Bacillus spp. in saline environments as well as their adaptation to the plant. However, soil salinity can affect rhizosphere bacterial diversity in normal circumstances and Szymańska reported that the number of endophytic bacteria and rhizosphere bacteria in halophyte S. europaea is small under extreme salinity conditions [42]. This may give us some hints about the high salt tolerance of Bacillus spp. Although only B16 could grow in medium with $10 \% \mathrm{NaCl}$, all strains grew well at $1 \%$ salt concentration, and the growth potential could reach $10 \%$. In short, 
the present results indicated that the diversity and function of Bacillus spp. might play an important role in the root micro-ecosystem in S. glauca.

\section{Acknowledgments}

This work was supported by the National Science Foundation of China (Grant No. 31970038), the Science Public Welfare Fund Projects of Zhejiang Province (Grant No. 2017C32050), and the Key Research and Development Projects of Zhejiang Province (Grant No. 2020C02030).

\section{Conflicts of Interest}

The authors have no financial conflicts of interest to declare.

\section{References}

1. Cai D, Rao Y, Zhan Y, Wang Q, Chen S. 2019. Engineering bacillus for efficient production of heterologous protein: current progress, challenge and prospect. J. Appl. Microbiol. 126: 1632-1642.

2. Nicholson WL. 2002. Roles of Bacillus endospores in the environment. Cell. Mol. Life Sci. 59: 410-416.

3. Abriouel H, Franz CMAP, Ben ON, Gálvez A. 2011. Diversity and applications of Bacillus bacteriocins. FEMS Microbiol. Rev. 35: 201232.

4. Jeżewska-Frąckowiak J, Seroczyńska K, Banaszczyk J, Jedrzejczak G, Żylicz-Stachula A, Skowron PM. 2018. The promises and risks of probiotic Bacillus species. Acta Biochim. Pol. 65: 509-519.

5. Lopes R, Tsui S, Goncalves PJRO, de Queiroz MV. 2018. A look into a multifunctional toolbox: endophytic Bacillus species provide broad and underexploited benefits for plants. World J. Microbiol. Biotechnol. 34: 94

6. Saxena AK, Kumar M, Chakdar H, Anuroopa N, Bagyaraj DJ. 2020. Bacillus species in soil as a natural resource for plant health and nutrition. J. Appl. Microbiol. 128: 1583-1594.

7. Radhakrishnan R, Hashem A, Abd Allah EF. 2017. Bacillus: a biological tool for crop improvement through bio-molecular changes in adverse environments. Front. Physiol. 8: 667.

8. Miljakovi D, Marinkovi J, Baleevi-Tubi S. 2020. The significance of Bacillus spp. in disease suppression and growth promotion of field and vegetable crops. Microorganisms 8: 1037.

9. Berendsen RL, Pieterse CMJ, Bakker PAHM. 2012. The rhizosphere microbiome and plant health. Trends Plant Sci. 17: $478-486$.

10. Jin H, Dong D, Yang Q. 2016. Salt-responsive transcriptome profiling of Suaeda glauca via RNA sequencing. PLoS One 11: e0150504.

11. Cui LJ, Pan X, Li W, Zhang XD, Liu GF, Song YB, et al. 2019. Phragmites australis meets Suaeda salsa on the "red beach": effects of an ecosystem engineer on salt-marsh litter decomposition. Sci. Total Environ. 693: 133477.

12. Duan HM, Ma YH, Liu RR, Li Q, Yang Y, Song J. 2018. Effect of combined waterlogging and salinity stresses on euhalophyte Suaeda glauca. Plant Physiol. Biochem. 127: 231-237.

13. Zhang HG, Yang BR, Chen AH, Liang HX. 2017. Soil microbial diversity of marshes covered by Suaeda salsa and Spartina alternifora in Yancheng Wetland. Nat. Environ. Pollut. Technol. 16: 1113-1119.

14. Xu ZK, Shao TY, Lv ZX, Yue Y, Liu AH, Long XH, et al. 2020. The mechanisms of improving coastal saline soils by planting rice. Sci. Total Environ. 703: 135529.

15. Rath M, Mitchell TR, Gold SE. 2018. Volatiles produced by Bacillus mojavensis RRC101 act as plant growth modulators and are strongly culture-dependent. Microbiol. Res. 208: 76-84.

16. Nishijima T, Toyota K, Mochizuki M. 2005. Predominant culturable Bacillus species in Japanese arable soils and their potential as biocontrol agents. Microbes Environ. 20: 61-68.

17. Sha YX, Zeng QC, Sui ST. 2020. Screening and application of Bacillus strains isolated from nonrhizospheric rice soil for the biocontrol of rice blast. Plant Pathol. 36: 231-243.

18. Ki JS, Zhang W, Qian PY. 2009. Discovery of marine Bacillus species by 16 S rRNA and rpoB comparisons and their usefulness for species identification. J. Microbiol. Methods 77: 48-57.

19. Jing CL, Xu ZC, Zou P, Tang Q, Li,YQ, You XW, et al. 2019. Coastal halophytes alter properties and microbial community structure of the saline soils in the Yellow River Delta, China. Appl. Soil Ecol. 134: 1-7.

20. Khan AG. 2005. Role of soil microbes in the rhizospheres of plants growing on trace metal contaminated soils in phytoremediation. J. Trace Elem. Med. Biol. 18: 355-364.

21. Fayez R. Salek-Gilani S. 2018. The potential activity of soil extracellular enzymes as an indicator for ecological restoration of rangeland soil after agricultural abandonment. Appl. Soil Ecol. 126: 140-147.

22. Shen Q, Hao YQ, Xu XH, Xu YD, Yang JY, Chu WY, et al. 2020. Analysis of rhizosphere bacterial diversity in Suaeda glauca Bunge based on high-throughput sequencing. J. Zhejiang Sci-Tech University 43: 671-677.

23. López-Angulo J, de la Cruz M, Chacón-Labella J, Illuminati A, Matesanz S, Pescador DS, et al. 2020. The role of root community attributes in predicting soil fungal and bacterial community patterns. New Phytol. 228: 1070-1082.

24. Yamamoto K, Shiwa Y, Ishige T, Sakamoto H, Tanaka K, Uchino M, et al. 2018. Bacterial diversity associated with the rhizosphere and endosphere of two halophytes: Glaux maritima and Salicornia europaea. Front. Microbiol. 9: 2878.

25. Bouizgarne B. 2013. Bacteria for plant growth promotion and disease management. pp. 15-47. In Maheshwari D. (ed.), Bacteria in Agrobiology: Disease Management, 2nd Ed. Springer Heidelberg New York Dordrecht, London.

26. Mukhtar S, Ishaq A, Hassan S, Mehnaz S, Mirza MS, Malik KA. 2017. Comparison of microbial communities associated with halophyte (Salsola stocksii) and non-halophyte (Triticum aestivum) using culture-independent approaches. Pol. J. Microbiol. 66: 353 364 .

27. Shi YW, Lou K, Li C, Wang L, Zhao ZY, Zhao S, et al. 2015. Illumina based analysis of bacterial diversity related to halophytes Salicornia europaea and Sueada aralocaspica. J. Microbiol. 53: 678-685.

28. Tian XY, Zhang CS. 2017. Illumina-based analysis of endophytic and rhizosphere bacterial diversity of the coastal halophyte Messerschmidia sibirica. Front. Microbiol. 8: 2288.

29. Brack C, Mikolasch A, Schlueter R, Otto A, Becher D, Wegner U, et al. 2015. Antibacterial metabolites and bacteriolytic enzymes produced by Bacillus pumilus during bacteriolysis of Arthrobacter citreus. Mar. Biotechnol. 17: 290-304.

30. Schinke C, Martins T, Queiroz SCN, Melo IS, Reyes FGR. 2017. Antibacterial compounds from marine bacteria, 2010-2015. J. Nat. Prod. 80: 1215-1228.

31. Fira D, Dimkic I, Beric T, Lozo J, Stankovic S. 2018. Biological control of plant pathogens by Bacillus species. J. Biotechnol. 285: 44-55.

32. Bais HP, Fall R, Vivanco JM. 2004. Biocontrol of Bacillus subtilis against infection of Arabidopsis roots by Pseudomonas syringae is facilitated by bioflm formation and surfactin production. Plant Physiol. 134: 307-319. 
33. Kupper KC, Corrêa FE, Azevedo FA, Silva AC. 2012. Bacillus subtilis to biological control of postbloom fruit drop caused by Colletotrichum acutatum under feld conditions. Sci. Hortic. 134: 139-143.

34. Kupper KC, Moretto RK, Fujimoto A. 2020. Production of antifungal compounds by Bacillus spp. isolates and its capacity for controlling citrus black spot under field conditions. World J. Microbiol. Biotechnol. 36: 1.

35. Asari S, S Matzén, Petersen MA, Bejai S, Meijer J, Sessitsch A. 2016. Multiple effects of Bacillus amyloliquefaciens volatile compounds: plant growth promotion and growth inhibition of phytopathogens. FEMS Microbiol. Ecol. 92: iw070.

36. Leelasuphakul W, Hemmanee P, Chuenchitt S. 2008. Growth inhibitory properties of Bacillus subtilis strains and their metabolites against the green mold pathogen (penicillium digitatum sacc.) of citrus fruit. Postharvest Biol. Technol. 48: 113-121.

37. Zhu L, Liu N, Wang H, Zhang Z, Jiang L, Huang H. 2019. Draft genome sequence of broad-spectrum antifungal-producing Bacillus velezensis C4341 isolated from a saline-alkali soil sample in China. J. Glob. Antbimicrob. Resist. 16: 291-293.

38. Kushwaha P, Kashyap PL, Srivastava AK, Tiwari RK. 2020. Plant growth promoting and antifungal activity in endophytic Bacillus strains from pearl millet (Pennisetum glaucum). Braz. J. Microbiol. 51: 229-241.

39. Singh RK, Singh P, Li HB, Song QQ, Guo DJ, Solanki MK, et al. 2020. Diversity of nitrogen-fixing rhizobacteria associated with sugarcane: a comprehensive study of plant-microbe interactions for growth enhancement in Saccharum spp. BMC Plant Biol. 20: 220.

40. Hong Y, Ma Y, Wu L, Maki M, Qin W, Chen S. 2012. Characterization and analysis of nifH genes from Paenibacillus sabinae T27. Microbiol. Res. 167: 596-60.

41. Szymańska S, Płociniczak T, Piotrowska-Seget Z, Hrynkiewicz K. 2016. Endophytic and rhizosphere bacteria associated with the roots of the halophyte Salicornia europaea L.-community structure and metabolic potential. Microbiol. Res. 192: 37-51. 